\title{
EDUCATIONAL HEALTH SERVICE IN FRANCE
}

Consequent upon war with its destruction and disruption, it is not uncommon for schemes to promote the people's health to receive encouragement from Governments and Treasuries. Not always, however, do even liberal projects survive when the administration finds it necessary to economize.

Dr. Auguste Robert* and Monsieur Ribadeau-Dumas $\dagger$ give an illustration of this familiar occurrence in papers dealing with the establishment and subsequent history of the Medical Directorate of School and University Health within the French Ministry of Education. Between the years 1945 and 1948 a co-ordinated National Educational Health Service was constructed out of the heretofore independent and imperfect pre-existing provincial municipal services. The School Health Service was expanded to include universities and other centres of higher education. Of 120,900 teachers who submitted themselves to radiological examination in 1948, 5,800 were classified as suspects and 235 were revealed as active cases of tuberculosis. Of the 100,000 students examined, 700 were found to be suffering from active tuberculosis.

Then, quite abruptly, in September, 1948, the Directorate was abolished without any reference to the National Academy of Medicine, which promulgated the uncompromising opinion that such action on the part of the newly appointed Cabinet was in conflict with the best interests of the country.

* “Trois Années d'Organisation et de Fonctionnement de l'Hygiène Scolaire en France (19451948)" par le Docteur Auguste Robert. Archives de Médecine Sociale, Juillet-Aout, 1949.

+ " Sur les Modifications apportées au Ministère de l'Education Nationale dans la direction de l'Hygiène scolaire et universitaire", par M. Ribadeau-Dumas. Bulletin de l'Académie Nationale de Médecine, No. 33 and 34, 1949, p. 629. 